С. М. Геряк, Н. І. Багній, І. В. Корда, О. Є. Стельмах, Н. В. Петренко ДВНЗ “Тернопільський державний медичний університет імені І. Я. Горбачевського МОЗ України”

\title{
СИМПТОМОКОМПЛЕКС СИНДРОМУ ЕМОЦІЙНОГО ВИГОРАННЯ ПРИ ВИКЛАДАННІ КЛІНІЧНИХ ДИСЦИПЛІН ІНОЗЕМНИМ СТУДЕНТАМ ТА ШЛЯХИ ЙОГО УСУНЕННЯ
}

\author{
S. M. Heryak, N. I. Bahniy, I. V. Korda, O. Y. Stelmakh, N. V. Petrenko \\ I. Horbachevsky Ternopil State Medical University

\section{EMOTIONAL BURNOUT SYNDROME IN CLINICAL DISCIPLINES FOR FOREIGN STUDENTS’ TEACHING AND WAYS OF THEIR SOLUTION}

\begin{abstract}
Викладачі клінічних кафедр вищої школи постійно перебувають під тиском подвійної відповідальності - викладацької та лікарської роботи, що поступово виснажує їх фізичні, розумові та психоемоційні ресурси.

У роботі розглянуто механізми виникнення та шляхи подолання синдрому емоційного вигорання при викладанні клінічних дисциплін іноземним студентам у вищій школі.

В умовах докорінних змін, що відбуваються у нашому суспільстві й системі вищої освіти, різко зростає роль і суть викладача вищої школи. Синдром емоційного вигорання розвивається набагато швидше у викладачів медичних ВНЗ, які викладають іноземною мовою внаслідок емоційно важких та напружених відносин у системі “викладач - студент-іноземець”, яка розвивається з часом. Це має безпосереднє значення для соціального та психологічного здоров’я викладача, відображається на його працездатності та продуктивності трудової діяльності, що потребує пошуку шляхів покращення умов роботи та додаткових психоемоційних розвантажень.

Результати спостережень за викладачами вищої медичної школи вказують на низку зовнішніх та внутрішніх причин, що сприяють появі синдрому емоційного вигорання у медичних працівників при викладанні клінічних дисциплін. Як правило, сприятливими умовами для розвитку даного синдрому є виникнення своєрідних психологічних ножиць між професійною компетентністю викладача (вмінням гнучко пристосовуватись до різних прототипів студента, здатністю розв'язувати конфлікти, при цьому залишаючись на високому рівні підготовки) та дефіцитом часу на виконання підготовки позааудиторних завдань і лікувальної роботи, виконання наукових досліджень, працю в бібліотеках тощо.

Заради досягнення позитивного результату як при викладанні дисципліни, так і в роботі з пацієнтами викладачу клінічної кафедри при роботі з іноземними студентами необхідно турбуватись про власне здоров’я та самопочуття. Саме формування та зміцнення професійного підходу до сприйняття інформації, іiї обробки та інтерпретації мають бути, на наш погляд, пріоритетними для такого викладача. Останнє дозволить підвищити пізнавальний та творчий потенціал викладача, покращити якість формування особистості майбутнього лікаря.
\end{abstract}

Ключові слова: викладач; емоційне вигорання; іноземні студенти.

The article adduces the mechanisms of the burnout syndrome appearance and ways to overcome emotional burnout in teaching of clinical courses to foreign students in higher education.

In terms of fundamental changes taking place in our society and higher education the role and essence of teacher of high school dramatically increases. Syndrome of emotional burnout develops much faster in the teachers of medical schools who work with foreign students as a result of severe emotional and tense relations in the system "teacher - student-foreigner" that develops over time. This has a direct relevance for social and psychological health teacher, appears on its efficiency and productivity of work that needs to find ways to improve working conditions and additional psycho-emotional unloading.

Observations by teachers of higher medical education point to a number of external and internal factors that are contributing to the syndrome of emotional burnout in health professionals in teaching clinical disciplines. Generally, favorable conditions for the development of this syndrome is the occurrence of peculiar psychological scissors between teacher professional competence (ability to flexibly adapt to different prototypes student's, ability to solve conflicts, while remaining at a high level of training) and lack of time on training and extracurricular tasks medical work, perform research, work in libraries and so on.

In order to achieve a positive outcome in teaching discipline, and work with patients, clinical lecturer in the department of foreign students should worry about their own health and well-being. It is the formation and strengthening professional approach to the perception of information, it's processing and interpretation should be, in our view, the priority for this teacher. The latter will increase the cognitive and creative potential of the teacher and improve future doctor formation quality.

Key words: teacher; emotional burnout; foreign students.

(c) С. М. Геряк, Н. І. Багній, I. В. Корда та ін. 
Підвищення інформаційного навантаження та психоемоційного пресингу, необхідність швидкого прийняття рішень, чисельність робочих програм з основних дисциплін, що викладаються у вищій школі, диктують викладачу необхідність постійно опановувати, демонструвати та осмислювати велику кількість наукових знань та практичних вмінь за відносний короткий проміжок часу.

Викладачі клінічних кафедр вищої школи постійно перебувають під тиском подвійної відповідальності - викладацької та лікарської роботи, що поступово виснажує їх фізичні, розумові та психоемоційні ресурси $[2,3,12]$.

Такий стан створює підгрунтя для розвитку синдрому емоційного вигорання (staff burnout syndrome), до якого більш схильні викладачі та працівники медичної галузі, як найбільше дотичні до вирішення чужих проблем люди [4-6]. Окрім цього, викладачу медичного ВНЗ у своїй професійній діяльності щодня доводиться мати справу з великою кількістю не лише студентів, а й пацієнтів, спілкування з якими нерідко відбувається в атмосфері постійного стресу та розумового перенапруження.

Таким чином, підняття такого питання, як “Симптомокомплекс синдрому емоційного вигорання при викладанні клінічних дисциплін іноземним студентам та шляхи його усунення”, особливо актуальне на сьогодні.

Щодо механізмів розвитку синдрому емоційного вигорання у працівників медичної та викладацької сфер психологи розрізняють три основні компоненти, що лягли в основу трифакторної моделі (розроблена К. Маслач та С. Джексон, 1986) [3, 9]. Трифакторність проявляється у психічному та фізичному виснаженні, наявності розладів самосприйняття та редукції індивідуальних дій із тенденцією до стереотипності [10].

Емоційне виснаження розглядається як основна складова вигорання і виявляється у зниженому емоційному фоні, байдужості або емоційному перенасиченні. Друга складова (деперсоналізація) позначається у деформації відносин з іншими людьми. В одних випадках це може бути підвищення залежності від тих, хто оточує. В інших - посилення негативізму, цинічного ставлення і відчуттів до реципієнтів: пацієнтів, студентів тощо. Третя складова вигорання - редукція особових досягнень - може виявлятися або тенденцією негативно оцінювати себе, занижувати свої професійні досягнення і успіхи, негативізмом до службових досягнень і можливостей, або зменшенням власної гідності, обмеженням своїх можливостей, обов'язків стосовно інших.

Запропоновані три компоненти вигорання певною мірою відображають специфіку професійної сфери “людина-людина”, у якій вперше був виявлений даний феномен. Особливо це стосується другого компонента вигорання - деперсоналізації [1].

Вигорання розуміється як професійна криза, яка пов'язана з роботою в цілому, а не тільки з міжособовими взаємовідношеннями в її процесі. Таке розуміння змусило взяти під сумнів певні зміни та поняття його основних компонентів: емоційного виснаження, цинізму, професійної ефективності. 3 цих позицій поняття деперсоналізації має більш широке значення і означає негативне ставлення не тільки до студентів чи пацієнтів, але і до роботи в цілому [3, 15, 16].

Оскільки емоційне вигорання - це вироблений особистістю механізм психологічного захисту у формі повного або часткового вимкнення емоцій (зниження їх енергетики) у відповідь на обрані психотравмуючі дії, так звані “процесуальні моделі” набувають значущості у розумінні феномену вигорання. У цьому контексті динаміка розвитку вигорання розглядається як зростання емоційного виснаження, внаслідок якого виникають негативні установки по відношенню до інших, особливо на роботі. Людина в такому стресі намагається створити емоційну дистанцію у відносинах з іншими як засіб здолання виснаження, проте паралельно розвивається і негативна установка ставлення до власних професійних досягнень - редукція професійних досягнень. Вигорання як динамічний процес, який розвивається у часі, характеризується збільшенням ступеня виявлення його проявлянь $[14,17]$.

Сьогодення вимагає перебудови підходів до організації як навчального процесу, так і особистого позаурочного часу викладача, що дасть можливість усунути психологічну напругу та попередити стан емоційного виснаження.

Результати спостережень за викладачами вищої медичної школи вказують на низку зовнішніх та внутрішніх причин, що сприяють появі синдрому емоційного вигорання у медичних працівників при викладанні клінічних дисциплін [4, 7, 8, 11].

До зовнішніх факторів належать:

1. Наявність хронічної напруженої розумової діяльності.

2. Специфічний контингент студентів (психологічні особливості самого студента-іноземця). 
3. Несвідоме перенесення проблем зі здоров’ям пацієнта на себе та на роботу із студентами.

4. Психологічна перевтома.

До внутрішніх чинників, що сприяють появі симптомокомплексу, відносять:

1. Психологічні особливості лікаря - надмірна чутливість, емоційність, сенситивність, наявність акцентуації різних рис характеру.

2. Інтенсивність роботи та стиль спілкування викладача відповідно до його темпераменту залежно від екстра- чи інтравертності, лабільності настрою.

Таким чином поступово формується контингент викладачів, які не здатні спланувати свій робочий час, ефективно розподілити професійні дії, швидко вичерпують свої професійні можливості. Однак без спеціальної медико-психологічної підготовки досить важко виявити, де, як і коли саме проявлятиметься комбінація згаданих симптомів.

Як правило, сприятливими умовами для розвитку даного синдрому є виникнення своєрідних психологічних ножиць між професійною компетентністю викладача (вмінням гнучко пристосовуватись до різних прототипів студента, здатністю розв'язувати конфлікти, при цьому залишаючись на високому рівні підготовки) та дефіцитом часу на виконання підготовки позааудиторних завдань і лікувальної роботи, виконання наукових досліджень, працю в бібліотеках тощо.

Стресова ситуація у вищій школі поглиблюється також за рахунок необхідності для викладача щодня розмовляти іноземною мовою, думати нею, враховувати лінгвістичні та професійні нюанси мовлення, специфіку етнічної та мовної належності студентів-медиків. Водночас робота з іноземними студентами вимагає від викладача бути особливо толерантним та обережним у висловлюваннях.

Отже, шляхи ліквідації симптомів емоційного виснаження у викладачів-медиків вищої школи, які проводять заняття іноземною мовою, на думку деяких авторів, слід розглядати у двох площинах - особистісній та професійній [6, 13].

Особистісна площина передбачає створення умов для заняття спортом, знаходження часу на улюб-

\section{Список літератури}

1. Большакова Т. В. Особистісні детермінанти й організаційні фактори виникнення психічного вигорання у медичних працівників : автореф. дис. канд. психол. наук: 19.00 .03 / Т. В. Большакова. - Ярославль, 2004. - 27 с.

2. Борисова М. В. Психологические детерминанты феномена эмоционального выгорания / М. В. Борисова // Вопросы психологии. - 2005. - № 2. - С. 97-104. лене хобі, вміння переключатись з одного виду діяльності на інший, можливість дбати про власне здоров’я та здоров'я оточуючих, гігієну життя та санацію конфліктів, уникнення спілкування та перебування в неприємному для особи колективі, зміну праці та виду діяльності загалом, вміння відволіктися з другорядних на основні речі (побути 3 родиною, приділити час дітям, відвідати виставки, концерти, вистави, перегляд кінофільмів) тощо.

У професійній площині синдром емоційного вигорання розглядається з різних точок зору. Залежно від превалювання конкретних ознак повинні мати місце: удосконалення професійних комунікативних навичок та вмінь в інших колективах, на тренінгах, міжнародних конгресах, школах тощо, робота над помилками в живому спілкуванні, тренінг мовної компетенції, динамічна зміна різних видів діяльності.

Висновки. В умовах докорінних змін, що відбуваються у нашому суспільстві й системі вищої освіти, різко зростає роль і суть викладача вищої школи. Заради досягнення позитивного результату як при викладанні дисципліни, так і в роботі з пацієнтами викладачу клінічної кафедри при роботі 3 іноземними студентами необхідно турбуватись про власне здоров'я та самопочуття. Саме формування та зміцнення професійного підходу до сприйняття інформації, її обробки та інтерпретації мають бути, на наш погляд, пріоритетними для такого викладача. Останнє дозволить підвищити пізнавальний та творчий потенціал викладача, покращити якість формування особистості майбутнього лікаря.

Синдром емоційного вигорання розвивається набагато швидше у викладачів медичних ВН3, які викладають іноземною мовою внаслідок емоційно важких та напружених відносин у системі “викладач - студент-іноземець”, яка розвивається з часом. Це має безпосереднє значення для соціального та психологічного здоров'я викладача, відображається на його працездатності та продуктивності трудової діяльності, що потребує пошуку шляхів покращення умов роботи та додаткових психоемоційних розвантажень.

3. Водопьянова Н. Е. Синдром выгорания: диагностика и профилактика / Н. Е. Водопьянова, Е. С. Старченкова. - 2-е изд. - Питер, 2008. - 336 с.

4. Геряк С. М. Формування компетентності молодих лікарів шляхом створення реальних життєвих ситуацій для студентів / С. М. Геряк // Медична освіта. - 2013. № 4. - С. 19-20. 
5. Косарев В. В. Неврозы у медицинских работников / В. В. Косарев, С. А. Бабанов // Здоров’я України. - 2011. - № 1. - C. 49.

6. Лембрик I. С. Синдром емоційного вигорання при викладанні дисципліни “Педіатрія” студентам старших курсів факультету підготовки іноземних громадян / I. С. Лембрик // Здоров’я дитини. - 2016. - № 7. - C. 130-134.

7. Liselotte N. Dyrbye. Relationship between work-home conflicts and burnout among american surgeons / Liselotte N. Dyrbye, Tait D. Shanafelt, Charles M. Balch [et al.] // Archives of Surgery. - 2011. - Vol. 146. - P. 211-217.

8. Paris M. Burnout in the mental health workforce: A review / M. Paris, M. A. Hoge, J. Behav // Health Serv. Res. - 2010. - Vol. 37, Is. 4. - P. 519-528.

9. Сидоров П. И. Синдром эмоционального выгорания (лекция) / П. И. Сидоров // Междунар. неврол. журн. 2007. - № 1 (11). - С. 129-140.

10. Трунов Д. О. И снова о “профессиональной деформации” / Д. О. Трунов // Психологическая газета. - 2004. - № 6. - С. 32-34.

11. Федак Б. С. Синдром выгорания у медицинских работников / Б. С. Федак // Медицинская психология. 2007. - T. 2, № 3. - C. 18-22.

\section{References}

1. Bolshakova, T.V. (2004). Osobystisni determinanty y orhanizatsiini faktory vynyknennia psykhichnoho vyhorannia u medychnykh pratsivnykiv [Personality determinants and organizational factors of mental burnout in health care workers]. Extended abstract of candidate's thesis [in Ukrainian].

2. Borisova, M.V. (2005). Psikhologicheskiye determinanty fenomena emotsionalnogo vygoraniya [Psychological determinants of the emotional burnout phenomenon]. Voprosy psikhologii - Questions of Psychology, 2, 97-104 [in Russian].

3. Vodopyanova, N.E., \& Starchenkova, E.S. (2008). Sindrom vygoraniya: diagnostika i profilaktika [Burnout Syndrome: Diagnosis and Prevention]. Piter [in Russian].

4. Heriak, S.M. (2013). Formuvannia kompetentnosti molodykh likariv shliakhom stvorennia realnykh zhyttievykh sytuatsiy dlia studentiv [Formation competence of young doctors by making real life situations for students]. $M e$ dychna osvita - Medical Education, 4, 19-20 [in Ukrainian].

5. Kosarev, V.V., \& Babanov, S.A. (2011). Nevrozy u meditsinskikh rabotnikov [Neurosis in health care workers]. Zdorovia Ukrainy - Ukraine Health, 1, 49 [in Russian].

6. Lembryk, I.S. (2016). Syndrom emotsiinoho vyhorannia pry vykladanni dystsypliny "Pediatriia“ studentam starshykh kursiv fakultetu pidhotovky inozemnykh hromadian [Syndrome of emotional burnout in teaching "Pediatrics" discipline for students of the faculty of foreign students]. Zdorovia dytyny - Children's Health, 7, 130-134 [in Ukrainian].
12. Чижма Д. М. Аналіз теоретичних підходів до проблеми саморегуляції особистості / Д. М. Чижма // Актуальні проблеми психології. Зб. наук. праць Інституту психології ім. Г. С. Костюка АПН України. Т. Х, вип. 4 / за ред. С. Д. Максименка. - К., 2008. - С. 333-340.

13. Kumar Shailesh. Burnout and Doctors: Prevalence, Prevention and Intervention / Shailesh Kumar // Healthcare. - 2016. - Vol. 4, Is. 3. - P. 1-9.

14. Freischlag J. Relationship between work-home conflicts and burnout among American surgeons: A comparison by sex / J. Freischlag // Arch. Surg. - 2011. Vol. 146. - P. 211-217.

15. The effectiveness of interventions in workplace health promotion as to maintain the working capacity of health care personal // B. Buchberger, R. Heymann, H. Huppertz [et al.] // GMS Health Technol. Assess. - 2011. - Vol. 7. Doc06. doi: 10.3205/hta000097. Epub 2011 Sep 28.

16. Van Wyk B. E. Preventive staff-support interventions for health wolkers / B. E. Van Wyk, V. Pillay-Van Wyk // Cochrane Database Syst. Rev. - 2010.

17. What are the significant factors associated with burnout in doctors? / E. Amoafo, N. Hanbali, A. Patel [et al.] // Occup. Med. - 2015. - Vol. 65. - P. 121-177.

7. Liselotte, N. Dyrbye, Tait, D. Shanafelt, Charles, M. Balch, Daniel, Satele, \& Jeff Sloan. (2011). Relationship between work-home conflicts and burnout among American surgeons. Archives of Surgery, 146, 211-217.

8. Paris, M., \& Hoge, M.A. (2010). Burnout in the mental health workforce: a review. Health Serv. Res. 37 (4), 519-528.

9. Sidorov, P.I. (2007). Sindrom emotsionalnogo vygoraniya (lektsiya) [Syndrome of emotional burnout (lecture)]. Mezhdunar. nevr. zhur. - International Neurological Journal, 1 (11), 129-140 [in Russian].

10. Trunov, D.O. (2004). I snova o "professionalnoy deformatsii” [And again about "professional deformation”]. Psikhologicheskaya gazeta - Psychological Newspaper, 6, 32-34 [in Russian].

11. Fedak, B.S. (2007). Sindrom vygoraniya u meditsinskikh rabotnikov [Burnout syndrome in health care workers]. Meditsinskaya psikhologiya - Medical Psychology, 2 (3), 18-22 [in Russian].

12. Chyzma, D.M. \& Maksymenko, S.D. (2008). Analiz teoretychnykh pidkhodiv do problemy samorehuliatsii osobystostosti [Analysis of theoretical issues to the problems of self-regulation]. Aktualni problemy psykholohii. Zb.nauk. prats Instytutu psykholohii im. H.S. Kostiuka APN Ukrainy - Actual problems of psychology. Collection of scientific works of the Institute of Psychology by H.S. Kostiuk of APS of Ukraine, 4, 333-340 [in Ukrainian].

13. Shailesh Kumar. (2016). Burnout and doctors: prevalence, prevention and intervention. Healthcare, 4 (37), 1-9. 
14. Freischlag, J. (2011). Relationship between workhome conflicts and burnout among American surgeons: A comparison by sex. Arch. Surg., 146, 211-217.

15. Buchberger, B., Heymann, R., \& Huppertz, H. (2011). The effectiveness of interventions in workplace health promotion as to maintain the working capacity of health care personal. GMS Health Technol. Assess., 7. Doc06. doi: 10.3205/hta000097. Epub 2011 Sep 28.

Електронна адреса для листування: geryak_svitlana@ukr.net
16. Van Wyk, B.E., \& Pillay-Van Wyk, V. (2010). Preventive staff-support interventions for health workers. Cochrane Database Syst. Rev.

17. Amoafo, E., Hanbali, N., \& Patel, A. (2015). What are the significant factors associated with burnout in doctors? Occup. Med., 65, 121-177. 